The University of San Francisco

USF Scholarship: a digital repository@ Gleeson Library |

Geschke Center

2000

\title{
Knudsen Cell Mass Spectrometric Investigation of the B2N Molecule
}

Giovanni Meloni

University of San Francisco, gmeloni@usfca.edu

M Sai Baba

Karl A. Gingerich

Follow this and additional works at: http://repository.usfca.edu/chem_fac

Part of the Chemistry Commons

\section{Recommended Citation}

Meloni, G., Baba, M. S., \& Gingerich, K. A. (2000). Knudsen cell mass spectrometric investigation of the B[sub 2]N molecule. Journal Of Chemical Physics, 113(20)

This Article is brought to you for free and open access by the Chemistry at USF Scholarship: a digital repository @ Gleeson Library| Geschke Center. It has been accepted for inclusion in Chemistry Faculty Publications by an authorized administrator of USF Scholarship: a digital repository @ Gleeson Library $\mid$ Geschke Center. For more information, please contact repository@usfca.edu. 


\title{
Knudsen cell mass spectrometric investigation of the $\mathrm{B}_{2} \mathrm{~N}$ molecule
}

\author{
G. Meloni, M. Sai Baba, ${ }^{\text {a) }}$ and K. A. Gingerich ${ }^{\text {b) }}$ \\ Department of Chemistry, Texas A\&M University, P.O. Box 30012, College Station, Texas 77842-3012
}

(Received 7 August 2000; accepted 29 August 2000)

\begin{abstract}
High-temperature Knudsen cell mass spectrometry has been used to study the equilibria involving the $\mathrm{B}_{2} \mathrm{~N}$ molecule over the $\mathrm{Si}-\mathrm{BN}$ system. Thermal functions needed in the evaluation of the mass spectrometric equilibrium data have been calculated from available experimental and theoretical molecular parameters. The enthalpy changes for the reactions $2 \mathrm{~B}(g)+\mathrm{Si}_{2} \mathrm{~N}(g)=\mathrm{B}_{2} \mathrm{~N}(g)$ $+2 \mathrm{Si}(g)$, and $\mathrm{BN}(s)+\mathrm{B}(g)=\mathrm{B}_{2} \mathrm{~N}(g)$ have been measured. The following atomization enthalpy, $\Delta_{a} H_{0}^{o}$, and enthalpy of formation, $\Delta_{f} H_{298.15}^{o}$, in $\mathrm{kJ} \mathrm{mol}^{-1}$, of $1045.5 \pm 18$ and $551.3 \pm 18$ for the $\mathrm{B}_{2} \mathrm{~N}$ molecule have been determined from these reaction enthalpies. Atomization energies of similar molecules have been compared and discussed. (C) 2000 American Institute of Physics.
\end{abstract}

[S0021-9606(00)01044-8]

\section{INTRODUCTION}

Boron-nitrogen clusters have been extensively investigated because of their importance to gain a deeper insight in boron nitride thin film formation through chemical vapor deposition (CVD) and to understand the interactions between the solid and gas phase during the thin film formation. This is essential for improving the processes of deposition of boron nitride. In addition, boron-nitrogen clusters have received attention recently because of the existence of fullerenes analogues involving boron and nitrogen atoms. ${ }^{1,2}$ In fact boron nitride is a structural analog to carbon, exhibiting bond length, long-order parameters, and lattice constants to be very similar to those of carbon.,

Boron nitride (BN) is a ceramic material mainly used as surface coating. BN exists in several allotropic forms including graphitelike $\alpha$-BN, and diamondlike $\beta$-BN. The $\beta$ form, or cubic phase, has significant technological potential for thin film application ${ }^{5}$ and rivals diamond in extreme hardness. It also has a number of highly desirable mechanical, thermal, electrical, and optical properties. ${ }^{4,5}$

Different techniques have been applied to study boronnitrogen containing molecules. Becker et al. ${ }^{6,7}$ used laser ionization mass spectrometry to study the formation of $\mathrm{B}_{n} \mathrm{~N}_{m}^{+}$ clusters ions in a laser plasma. They observed that for $\mathrm{B}_{n} \mathrm{~N}_{n-1}^{+}$and $\mathrm{B}_{n} \mathrm{~N}_{n-2}^{+}$cluster ions there is an alternating abundance distribution with the higher intensities of the cluster ions with the odd number of atoms. Andrews and coworkers reacted boron and nitrogen atoms in nitrogen ${ }^{8}$ or $\operatorname{argon}^{9}$ matrices. They identified BBNN, cyclic $\mathrm{B}_{2} \mathrm{~N}, \mathrm{BNB}$, NNBN, and BNBN from mixed isotopic patterns, and isotopic shifts, using Fourier transform infrared spectroscopy and ab initio calculations. Knight et al. ${ }^{10}$ used a laser vaporization matrix isolation electron spin resonance (ESR) apparatus to study the BNB radical. They found that BNB has an $X^{2} \Sigma_{u}^{+}$ground electronic state with a linear centrosymmetric

\footnotetext{
${ }^{a}$ Present address: Materials Chemistry Division, Indira Gandhi Center for Atomic Research, Kalapakkam 603 102, Tamil Nadu, India.

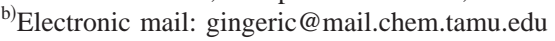

structure. Roland and Wynne ${ }^{11}$ described photoionization and photofragmentation of $\mathrm{B}_{x} \mathrm{~N}_{y}$ clusters generated by laser vaporization of boron nitride followed by supersonic expansion. Thompson et al. ${ }^{12,13}$ studied the infrared (IR) spectra of reaction products of laser ablated boron atoms with ammonia, during condensation with excess argon at $10 \mathrm{~K}$. They observed cyclic and symmetric linear $\mathrm{B}_{2} \mathrm{~N}$ together with a series of hydrogen-boron-nitrogen containing species. Asmis et al. ${ }^{14-17}$ employed a negative ion tandem TOF (timeof-flight) photoelectron spectrometer to determine adiabatic detachment energies and vibrational frequencies for several low-lying electronic states of $\mathrm{BN}, \mathrm{B}_{2} \mathrm{~N}$, and $\mathrm{B}_{3} \mathrm{~N}$. In particular Asmis et al. ${ }^{16}$ found no evidence for a low-lying cyclic isomer of $\mathrm{B}_{2} \mathrm{~N}$. They reassigned the matrix IR spectra of Andrews and co-workers ${ }^{9,12,13}$ to the $X^{2} \Sigma_{u}^{+}$ground state of linear $\mathrm{B}_{2} \mathrm{~N}$.

A large number of theoretical studies have been carried out on $\mathrm{BN},{ }^{18-23}$ and polyatomic boron-nitrogen clusters. ${ }^{16,24-31}$ The main aim of the computations on boronnitrogen clusters was to optimize their structures, to calculate the relative stability of different isomers, the vibrational frequencies, the ionization energies and the electron affinities, and to estimate the atomization energies.

In continuation of our recent investigations on small nitrogen containing group 13 and 14 clusters, ${ }^{32-37}$ we employed the Knudsen cell mass spectrometric method to perform the first equilibrium study on $\mathrm{B}_{2} \mathrm{~N}$ and to determine its atomization energy and enthalpy of formation. A preliminary value for the atomization energy of $\mathrm{B}_{2} \mathrm{~N}$ has previously been reported. ${ }^{32}$

\section{THEORETICAL INVESTIGATIONS}

$A b$ initio calculations were carried out utilizing the GAUSSIAN 98 program package ${ }^{38}$ in order to gain information about the ionization energy (IE), electron affinity (EA), and atomization enthalpy $\left(\Delta_{a} H_{0}^{o}\right)$ of the ground state of $\mathrm{B}_{2} \mathrm{~N}$. The calculations were performed at the density-functional level of theory using the Becke three-parameter exchange functional with the Lee, Yang, and Parr correlational func- 
TABLE I. Comparison between our calculations and the experimental molecular parameters, electron affinity (EA), ionization energy (IE), and atomization enthalpy $\left(\Delta_{a} H_{0}^{o}\right)$ of the $X^{2} \Sigma_{u}^{+} \mathrm{B}_{2} \mathrm{~N}$ molecule and of the $X^{2} \Pi_{g} \mathrm{Si}_{2} \mathrm{~N}$ molecule.

\begin{tabular}{|c|c|c|c|c|c|c|c|}
\hline Method/Basis set & $\begin{array}{c}r_{\mathrm{X}-\mathrm{N}}{ }^{\mathrm{a}} \\
(X=\mathrm{B} \text { or } \mathrm{Si})\end{array}$ & $\nu_{1}{ }^{\mathrm{b}}$ & $\nu_{2}$ & $\nu_{3}$ & $\mathrm{EA}^{\mathrm{c}}$ & IE & $\Delta_{a} H_{0}^{o \mathrm{~d}}$ \\
\hline \multicolumn{8}{|l|}{$\mathrm{B}_{2} \mathrm{~N}$ molecule } \\
\hline B3LYP/cc-pVTZ & 1.313 & 1195 & 125 & 1326 & 2.885 & 10.67 & 1102 \\
\hline $\mathrm{G} 1^{\mathrm{e}}$ & 1.327 & 1183 & 153 & 2392 & 3.34 & 8.65 & 1050 \\
\hline MP4(SDTQ)/6-31G*f & 1.338 & & & & & & \\
\hline $\operatorname{CCSD}(\mathrm{T}) / \mathrm{aug}-\mathrm{cc}-\mathrm{pVTZ} \mathrm{Z}^{\mathrm{g}}$ & 1.328 & 1143 & 85 & $i 1320$ & 3.139 & & \\
\hline APES $^{\text {h }}$ & & 1143 & & 855 & 3.098 & & \\
\hline KC-MS ${ }^{\mathrm{i}}$ & & & & & & 9.7 & 1046 \\
\hline \multicolumn{8}{|l|}{$\mathrm{Si}_{2} \mathrm{~N}$ molecule } \\
\hline B3LYP/cc-pVTZ & 1.638 & 615 & 223 & 1066 & 0.914 & 6.34 & 974 \\
\hline $\operatorname{CCSD}(\mathrm{T}) / \mathrm{cc}-\mathrm{pVTZ}$ & 1.644 & 614 & 187 & 917 & & & \\
\hline $\mathrm{R}_{2} \mathrm{PIS} \mathrm{S}^{\mathrm{k}}$ & 1.640 & & & & & $<8.51$ & \\
\hline KC-MS ${ }^{1}$ & & & & & & 6.6 & 1011 \\
\hline
\end{tabular}

${ }^{\mathrm{a}}$ The bond lengths are in $\AA$.

${ }^{\mathrm{b}} \nu_{1}$ is the symmetric stretching $\left(\sigma_{g}\right), \nu_{3}$ the antisymmetric stretching $\left(\sigma_{u}\right)$, and $\nu_{2}$ the bending vibrational mode, in $\mathrm{cm}^{-1}$.

${ }^{\mathrm{c}} \mathrm{EA}$ and IE are in $\mathrm{eV}$.

${ }^{\mathrm{d}} \Delta_{a} H_{0}^{o}$ is in $\mathrm{kJ} \mathrm{mol}^{-1}$.

${ }^{\mathrm{e}} \mathrm{G} 1$ is for GAUSSIAN 1 theory, see Ref. 25.

${ }^{\mathrm{f}}$ Reference 10.

${ }^{\mathrm{g}}$ Reference 16

${ }^{\mathrm{h}} \mathrm{APES}$ is for anion photoelectron spectroscopy, see Ref. 16.

${ }^{\mathrm{i}} \mathrm{KC}-\mathrm{MS}$ is for Knudsen cell mass spectrometry (present investigation).

${ }^{\mathrm{j}}$ Reference 39.

${ }^{\mathrm{k}} \mathrm{R} 2 \mathrm{PI}$ is for resonant two-photon ionization spectroscopy, see Ref. 40

${ }^{1}$ Reference 34.

tional (B3LYP). The basis set employed for this study was a correlated consistent polarized valence triple-zeta basis set, cc-pVTZ.

From the calculations the lowest lying ${ }^{2} \Sigma_{u}^{+}$electronic state is found to have the linear symmetric structure in agreement with experimental ${ }^{10,15,16}$ and theoretical ${ }^{9,10,16,24,25}$ literature data. This result is also in agreement with experimental and theoretical results for similar molecules, $\mathrm{Si}_{2} \mathrm{~N},{ }^{39,40}$ and $\mathrm{Al}_{2} \mathrm{~N},{ }^{37,41}$ which too have linear symmetric structures as the most stable ground-state geometry.

The vibrational frequencies for the three vibrational normal modes, the optimized bond lengths, and the physical chemical properties, corrected for the zero-point energies (ZPE), of the $X^{2} \Sigma_{u}^{+}$state for $\mathrm{B}_{2} \mathrm{~N}$ are listed in Table I, and compared with available experimental and theoretical values. The calculated EA of $\mathrm{B}_{2} \mathrm{~N}$ at the B3LYP/cc-pVTZ level of theory is about $7 \%$ lower than the experimental value of $(3.098 \pm 0.005) \mathrm{eV} .{ }^{16}$

In order to support our computations, we calculated the bond distances, vibrational frequencies, electron affinity, ionization energy, and atomization enthalpy for the $\mathrm{Si}_{2} \mathrm{~N}$ molecule at the same level of theory used for $\mathrm{B}_{2} \mathrm{~N}$, and compared them with available experimental and theoretical values. The results are reported in Table I. Our computed silicon-nitrogen bond distance practically coincides with the experimental value of $(1.6395 \pm 0.0014) \AA$ by Brugh and Moorse. ${ }^{40}$ The computed IE of $6.34 \mathrm{eV}$ of $\mathrm{Si}_{2} \mathrm{~N}$ agrees with the value of $(6.6 \pm 0.5) \mathrm{eV}$ obtained from the linear extrapolation method by Gingerich et al. ${ }^{34}$

Asmis et al. ${ }^{16}$ measured the symmetric and antisymmetric vibrational modes of $\mathrm{B}_{2} \mathrm{~N}$ by anion photoelectron spec- troscopy. The calculated symmetric stretching mode agrees with the experimental value of $1143 \mathrm{~cm}^{-1}$ at all levels of theory used, B3LYP/cc-pVTZ, Gaussian 1 (G1), and $\operatorname{CCSD}(\mathrm{T}) /$ aug-cc-pVTZ, but the calculations of the asymmetric stretching mode, $\nu_{3}$, failed in reproducing the experimental value of $855 \mathrm{~cm}^{-1}$. This problem has been explained by a distortion along the asymmetric stretch coordinate yielding a wave function which is oversimplified and leading to an artifactual structure on the potential energy surface. ${ }^{16}$ The surprisingly low experimental value of $\nu_{3}$ has been attributed to Herzberg-Teller coupling between the $X^{2} \Sigma_{u}^{+}$and the low-lying $A^{2} \Sigma_{g}^{+}$excited state. ${ }^{16}$

\section{EXPERIMENT}

The mass spectrometer and experimental procedures used for this work have been described previously. ${ }^{42}$ The sample of semiconductor grade silicon powder and $\mathrm{Si}_{3} \mathrm{~N}_{4}$ of 99.9\% purity was contained in a boron nitride Knudsen cell, which was inserted into a graphite cell having a molybdenum lid. The molybdenum lid intended to minimize the formation of disilicon carbide, $\mathrm{Si}_{2} \mathrm{C}$, and the overlap of its isotope with those of $\mathrm{Si}_{2} \mathrm{~N}$. The $\mathrm{Si}_{3} \mathrm{~N}_{4}$ had decomposed almost completely in the temperature range of present measurements, and the boron nitride served as the source of nitrogen. The liquid silicon also served as a catalyst for the equilibration of $\mathrm{BN}$ with the nitrogen containing species, ${ }^{43}$ since $\mathrm{BN}$ has a lowvaporization coefficient lower than $6 \times 10^{-3} .{ }^{44}$

The Knudsen cell was heated by radiation from a tungsten coil resistor and the temperatures were measured with a calibrated Leeds and Northrup optical pyrometer focused 
TABLE II. Measured relative ion currents, in $\mathrm{A}$, over the $\mathrm{Si}-\mathrm{BN}$ system, and third-law values, in $\mathrm{kJ} \mathrm{mol}{ }^{-1}$, of the $\Delta_{r} H_{0}^{o}$ and $\Delta_{a} H_{0}^{o}$ of $\mathrm{B}_{2} \mathrm{~N}$.

\begin{tabular}{|c|c|c|c|c|c|c|c|c|}
\hline \multirow[b]{2}{*}{$T(\mathrm{~K})$} & \multicolumn{4}{|c|}{ Ion intensities } & \multirow{2}{*}{$\begin{array}{c}\Delta_{r} H_{0}^{o} \\
\text { Reaction (1) }\end{array}$} & \multirow[b]{2}{*}{$\Delta_{a} H_{0}^{o}$} & \multirow{2}{*}{$\begin{array}{c}\Delta_{r} H_{0}^{o} \\
\text { Reaction (2) }\end{array}$} & \multirow[b]{2}{*}{$\Delta_{a} H_{0}^{o}$} \\
\hline & $\mathrm{B}^{+}$ & $\mathrm{Si}_{2} \mathrm{~N}^{+}$ & $\mathrm{Si}^{+}$ & $\mathrm{B}_{2} \mathrm{~N}^{+}$ & & & & \\
\hline 2066 & $1.10 E-12$ & $2.70 E-12$ & $2.04 E-10$ & $5.30 E-15$ & -35.72 & 1046.3 & 238.2 & 1040.6 \\
\hline 2082 & $1.55 E-12$ & $3.80 E-12$ & $2.75 E-10$ & $9.54 E-15$ & -38.71 & 1049.3 & 235.7 & 1043.1 \\
\hline 2119 & $1.88 E-12$ & $8.20 E-12$ & $3.12 E-10$ & $2.10 E-14$ & -37.36 & 1047.9 & 229.4 & 1049.4 \\
\hline 2146 & $2.32 E-12$ & $1.27 E-12$ & $1.87 E-10$ & $1.68 E-14$ & -41.33 & 1051.9 & 240.0 & 1038.8 \\
\hline 2095 & $8.71 E-13$ & $3.43 E-13$ & $9.30 E-11$ & $2.88 E-15$ & -42.28 & 1052.8 & 248.0 & 1030.8 \\
\hline 2052 & $8.69 E-13$ & $2.94 E-13$ & $6.10 E-11$ & $3.87 E-15$ & -34.81 & 1045.4 & 237.9 & 1040.9 \\
\hline \multirow[t]{2}{*}{2135} & $1.92 E-12$ & $6.65 E-13$ & $1.12 E-10$ & $1.91 E-14$ & -43.11 & 1054.0 & 233.1 & 1045.7 \\
\hline & & & & & $-39.1 \pm 3.3^{\mathrm{a}}$ & $1049.7 \pm 3.3$ & $237.5 \pm 5.9$ & $1041.3 \pm 5.9$ \\
\hline
\end{tabular}

${ }^{\text {aThe error terms are standard deviations. }}$

onto a black body hole at the bottom of the graphite cell. Appropriate window and prism corrections were applied. The ions were produced with ionizing electrons and electron emission current of $12 \mathrm{eV}$ and $10 \mathrm{~mA}$, respectively. The acceleration voltage used was $4.5 \mathrm{kV}$ and the electron multiplier was operated at $-3 \mathrm{kV}$.

The ions pertinent to the present investigation were $\mathrm{B}^{+}$, $\mathrm{Si}^{+}, \mathrm{Si}_{2} \mathrm{~N}^{+}$, and $\mathrm{B}_{2} \mathrm{~N}^{+}$. The ions were identified by their mass-to-charge ratio, isotopic abundance, and ionization efficiency curves. At each measurement a movable slit was interposed into the molecular beam to distinguish between ions produced from species in the beam and from residual gases with the same mass-to-charge ratio in the ionization region of the mass spectrometer. The electron impact energy was calibrated against the first ionization energy of B (8.296 $\mathrm{eV})^{45}$ and $\mathrm{Si}(8.149 \mathrm{eV}){ }^{45}$ The appearance potential of $(9.7$ $\pm 0.5) \mathrm{eV}$ was measured for $\mathrm{B}_{2} \mathrm{~N}$ by the linear extrapolation method. The measured appearance potential is $9 \%$ lower than our computed value of $10.67 \mathrm{eV}$ (see Table I), and $12 \%$ higher than the G1 value of $8.65 \mathrm{eV}^{25}$

The ion current data of the species pertinent to this investigation are listed in Table II. In the case of $\mathrm{B}_{2} \mathrm{~N}$ the ion intensities at mass 35 were measured due to better signal-tonoise ratio; for all other species the maximum intensity peaks were recorded. The ion intensity of $\mathrm{Si}_{2} \mathrm{~N}^{+}$in Table II has been corrected for a small contribution due to $\mathrm{Si}_{2} \mathrm{C}$; the maximum correction was $10 \%$ at $m / e=70$.

\section{RESULTS AND DISCUSSION}

For the determination of the enthalpy of formation, $\Delta_{f} H_{0}^{o}$, and the enthalpy of atomization, $\Delta_{a} H_{0}^{o}$, of $\mathrm{B}_{2} \mathrm{~N}$, the enthalpy changes of the following reactions:

$$
\begin{aligned}
& 2 \mathrm{~B}(g)+\mathrm{Si}_{2} \mathrm{~N}(g)=\mathrm{B}_{2} \mathrm{~N}(g)+2 \mathrm{Si}(g), \\
& \mathrm{BN}(s)+\mathrm{B}(g)=\mathrm{B}_{2} \mathrm{~N}(g),
\end{aligned}
$$

were evaluated according to the third-law method, using the relation $\Delta_{r} H_{0}^{o}=-R T \ln K_{p}-T \Delta\left[\left(G_{T}^{o}-H_{0}^{o}\right) / T\right]$.

The Gibbs energy functions, $\left(G_{T}^{o}-H_{0}^{o}\right) / T\left(\mathrm{GEF}_{0}\right)$, and the heat content functions, $H_{T}^{o}-H_{0}^{o}\left(\mathrm{HCF}_{0}\right)$, needed in the evaluation of the reactions enthalpies were taken from literature for $\mathrm{B}(g),{ }^{46} \mathrm{Si}(g)$ (Ref. 46, Vol. 2), $\mathrm{BN}(s),{ }^{46}$ and $\mathrm{Si}_{2} \mathrm{~N}(g) .{ }^{34}$ Those for $\mathrm{B}_{2} \mathrm{~N}(g)$ were computed according to statistical thermodynamic procedures, using the rigid-rotator harmonic-oscillator approximation ${ }^{47}$ and the molecular constants computed at the $\operatorname{CCSD}(\mathrm{T}) / \mathrm{aug}-\mathrm{cc}-\mathrm{pVTZ}$ level of theory by Asmis et al., ${ }^{16}$ bond distance of $1.328 \AA$ and bending vibrational mode of $85 \mathrm{~cm}^{-1}$ for which there are no experimental values. These values have been preferred to those calculated at the B3LYP/cc-pVTZ level of theory because of the higher level of theory used. For the asymmetric and symmetric vibrational frequencies the experimental values of 855 and $1143 \mathrm{~cm}^{-1}$, respectively, were used. ${ }^{16}$ The $A^{2} \Sigma_{g}^{+}$excited state with the transition energy $\left(T_{e}\right)$ of 6330 $\mathrm{cm}^{-1}$ (Ref. 16) was also considered. Table III lists the thermal functions of $\mathrm{B}_{2} \mathrm{~N}$.

Reactions (1) and (2) are pressure independent, therefore, the measured ion intensities listed in Table II were utilized directly to calculate the equilibrium constant of the reactions (1) and (2), after correcting them for the isotopic abundance and ionization cross sections. For the multiplier gains cancellation of mass and molecular effects was assumed. The isotopic abundance of the atomic species was taken from Kiser, ${ }^{48}$ and those of the molecular species were calculated from the isotopic abundance of the constituent elements. The relative ionization cross section used, $\sigma$, in $10^{-16} \mathrm{~cm}^{2}$, were taken from experimental values reported in the literature, except for $\mathrm{B}$, where a calculated value was used: $\mathrm{B}, 0.72 ;^{49} \mathrm{Si}, 3.34 ;^{50} \mathrm{~N}, 0.05 ;^{51} \mathrm{Si}_{2} \mathrm{~N}, 5.69$ as 0.75 $\times\left(2 \sigma_{\mathrm{Si}}+\sigma_{\mathrm{N}}\right) ; \mathrm{B}_{2} \mathrm{~N}, 1.12$ as $0.75 \times\left(2 \sigma_{\mathrm{B}}+\sigma_{\mathrm{N}}\right)$.

The literature values for the enthalpies of formation, $\Delta_{f} H_{0}^{o}$, in $\mathrm{kJ} \mathrm{mol}^{-1}$, used to obtain the final values for the enthalpy of formation and atomization of $\mathrm{B}_{2} \mathrm{~N}$ were: $559.9 \pm 5.0,^{46} 445.7 \pm 8.0,^{46}-248.1 \pm 1.0,^{46} 351.6 \pm 14.8,^{34}$ and $470.8 \pm 0.1,{ }^{52}$ for $\mathrm{B}(g), \mathrm{Si}(g), \mathrm{BN}(s), \mathrm{Si}_{2} \mathrm{~N}(g)$, and $\mathrm{N}(g)$, respectively. From the $\Delta_{r} H_{0}^{o}$ values, see Table II, and

TABLE III. The Gibbs energy functions, $\left(G_{T}^{o}-H_{0}^{o}\right) / T\left(\mathrm{GEF}_{0}\right)$, in $\mathrm{J} \mathrm{K}^{-1} \mathrm{~mol}^{-1}$, and the heat content functions, $H_{T}^{o}-H_{0}^{o}\left(\mathrm{HCF}_{0}\right)$, in $\mathrm{kJ} \mathrm{mol}^{-1}$, for the $\mathrm{B}_{2} \mathrm{~N}$ molecule.

\begin{tabular}{cccccccc}
\hline \hline & \multicolumn{7}{c}{ Temperature (K) } \\
\cline { 2 - 7 } Species & & 298.15 & 1400 & 1600 & 1800 & 2000 & 2200 \\
\hline \multirow{2}{*}{$\mathrm{B}_{2} \mathrm{~N}$} & $-\mathrm{GEF}_{0}$ & 201.8 & 277.4 & 284.7 & 291.3 & 297.3 & 302.7 \\
& $\mathrm{HCF}_{0}$ & 12.91 & 76.51 & 88.87 & 101.4 & 114.0 & 126.7 \\
\hline \hline
\end{tabular}


these auxiliary literature data the respective $\Delta_{f} H_{0}^{o}$ and $\Delta_{a} H_{0}^{o}$ were derived, using the following relations: for reaction (1), $\quad \Delta_{f} H_{0}^{o}\left(\mathrm{~B}_{2} \mathrm{~N}, g\right)=\Delta_{r} H_{0}^{o}-2 \Delta_{f} H_{0}^{o}(\mathrm{Si}, g)+2 \Delta_{f} H_{0}^{o}(\mathrm{~B}, g)$ $+\Delta_{f} H_{0}^{o}\left(\mathrm{Si}_{2} \mathrm{~N}, g\right) \quad$ and $\quad \Delta_{a} H_{0}^{o}\left(\mathrm{~B}_{2} \mathrm{~N}, g\right)=2 \Delta_{f} H_{0}^{o}(\mathrm{~B}, g)$ $+\Delta_{f} H_{0}^{o}(\mathrm{~N}, g)-\Delta_{f} H_{0}^{o}\left(\mathrm{~B}_{2} \mathrm{~N}, g\right) ; \quad$ for reaction $\Delta_{f} H_{0}^{o}\left(\mathrm{~B}_{2} \mathrm{~N}, g\right)=\Delta_{r} H_{0}^{o}+\Delta_{f} H_{0}^{o}(\mathrm{~B}, g)+\Delta_{f} H_{0}^{o}(\mathrm{BN}, s)$.

By giving the same weight to both reactions employed in the present investigation, we obtain the values, in $\mathrm{kJ} \mathrm{mol}^{-1}$ : $1045.5 \pm 18, \quad 1051.4 \pm 18,545.2 \pm 18$, and $551.3 \pm 18$ for $\Delta_{a} H_{0}^{o}, \Delta_{a} H_{298.15}^{o}, \Delta_{f} H_{0}^{o}$, and $\Delta_{f} H_{298.15}^{o}$ of $\mathrm{B}_{2} \mathrm{~N}(g)$, respectively. Here the uncertainties are the overall errors obtained as discussed by Schmude et al. ${ }^{53}$

Our computed $\Delta_{a} H_{0}^{o}\left(\mathrm{~B}_{2} \mathrm{~N}, g\right)$ value of $1102 \mathrm{~kJ} \mathrm{~mol}^{-1}$ is about $5 \%$ higher than the experimental value, and the scaled $\mathrm{CCD}+\mathrm{STD}(\mathrm{CCD}) / 6-31 \mathrm{G}^{*}$ value of $1109 \mathrm{~kJ} \mathrm{~mol}^{-1}$ (Ref. 24) is about $6 \%$ higher than our experimental value. The G1 $\Delta_{a} H_{0}^{o}\left(\mathrm{~B}_{2} \mathrm{~N}, g\right)$ value of $1050 \mathrm{~kJ} \mathrm{~mol}^{-1}$ (Ref. 25) is in good agreement with our experimental value.

It is interesting to compare the thermodynamic stability of similar molecules. The atomization energy, in $\mathrm{kJ} \mathrm{mol}^{-1}$, of $\mathrm{B}_{2} \mathrm{~N}, \mathrm{~B}_{2} \mathrm{C},{ }^{46} \mathrm{~B}_{2} \mathrm{O},{ }^{25} \mathrm{Al}_{2} \mathrm{~N},{ }^{37} \mathrm{Al}_{2} \mathrm{C},{ }^{54} \mathrm{Al}_{2} \mathrm{O}^{46}$ are: $1045 \pm 18$, $1060 \pm 30,1211 \pm 8,783 \pm 15,852 \pm 42$, and $1050 \pm 20$, respectively. The $\Delta_{a} H_{0}^{o}$ of $\mathrm{Al}_{2} \mathrm{C}$ was estimated by Gurvich et al. ${ }^{54}$ from the relative abundance of $\mathrm{Al}_{2} \mathrm{C}^{+}$observed by Chupka et al. ${ }^{55}$ For $\mathrm{B}_{2} \mathrm{O}$ the theoretical value based on the G1 method has been used since no reliable experimental value is available.

The thermodynamic stability of the $\mathrm{B}_{2}-\mathrm{X}$ and $\mathrm{Al}_{2}-\mathrm{X}$ type molecules $(\mathrm{X}=\mathrm{N}, \mathrm{C}$, and $\mathrm{O})$ increases with the replacement of $\mathrm{N}$ by $\mathrm{C}$ and $\mathrm{C}$ by $\mathrm{O}, \mathrm{B}_{2} \mathrm{O}$ and $\mathrm{Al}_{2} \mathrm{O}$ being the most stable. $\mathrm{B}_{2} \mathrm{~N}$ and $\mathrm{B}_{2} \mathrm{C}$, as well as $\mathrm{Al}_{2} \mathrm{~N}$ and $\mathrm{Al}_{2} \mathrm{C}$, have comparable stability.

\section{ACKNOWLEDGMENTS}

$A b$ initio calculations were performed on a workstation (Power Challenge, Silicon Graphics with twelve R10000 CPUs) in the Department of Chemistry at Texas A\&M University, supported by NSF Grant No. CHE-9528196. The authors wish to thank the Robert A. Welch Foundation for financial support of this work.

${ }^{1}$ O. Stéphan, Y. Bando, A. Loiseau, F. Willaime, N. Shramchenko, T. Tamiya, and T. Sato, Appl. Phys. A: Mater. Sci. Process. 67, 107 (1998).

${ }^{2}$ D. Golberg, Y. Bando, O. Stéphan, and K. Kurashima, Appl. Phys. Lett. 73, 2441 (1998).

${ }^{3}$ X. Blase, A. Rubio, S. G. Louie, and M. L. Cohen, Europhys. Lett. 28, 335 (1994)

${ }^{4}$ Synthesis and Properties of Boron Nitride, edited by J. J. Pouch and S. A. Alterovitz (Materials Science Forum, Trans Tech Publications, Zurich, 1990), Vols. 54 and 55.

${ }^{5}$ P. B. Mirkarimi, K. F. McCarty, and D. L. Medlin, Mater. Sci. Eng., R. 21, 47 (1997).

${ }^{6}$ S. Becker and H.-J. Dietze, Int. J. Mass Spectrom. Ion Processes 73, 157 (1986).

${ }^{7}$ S. Becker, H.-J. Dietze, G. Keßler, H.-D. Bauer, and W. Pompe, Z. Phys. B: Condens. Matter 81, 47 (1990).

${ }^{8}$ P. Hassanzadeh and L. Andrews, J. Phys. Chem. 96, 9177 (1992).

${ }^{9}$ L. Andrews, P. Hassanzadeh, T. R. Burkholder, and J. M. L. Martin, J. Chem. Phys. 98, 922 (1993).

${ }^{10}$ L. B. Knight, Jr., D. W. Hill, T. J. Kirk, and C. A. Arrington, J. Phys. Chem. 96, 555 (1992).

${ }^{11}$ P. A. Roland and J. J. Wynne, J. Chem. Phys. 99, 8599 (1993).

${ }^{12}$ C. A. Thompson and L. Andrews, J. Am. Chem. Soc. 117, 10125 (1995).
${ }^{13}$ C. A. Thompson, L. Andrews, J. M. L. Martin, and J. El-Yazal, J. Phys. Chem. 99, 13839 (1995).

${ }^{14}$ K. R. Asmis, T. R. Taylor, and D. M. Neumark, Chem. Phys. Lett. 295, 75 (1998).

${ }^{15}$ K. R. Asmis, T. R. Taylor, and D. M. Neumark, Eur. Phys. J. D 9, 257 (1999).

${ }^{16}$ K. R. Asmis, T. R. Taylor, and D. M. Neumark, J. Chem. Phys. 111, 8838 (1999).

${ }^{17}$ K. R. Asmis, T. R. Taylor, and D. M. Neumark, J. Chem. Phys. 111, 10491 (1999).

${ }^{18}$ R. R. Reddy, A. S. R. Reddy, and T. V. R. Rao, Physica B \& C 132, 373 (1985).

${ }^{19}$ J. M. L. Martin, J. P. François, and R. Gijbels, Z. Phys. D: At., Mol. Clusters 21, 47 (1991).

${ }^{20}$ J. M. L. Martin, T. J. Lee, G. E. Scuseria, and P. R. Taylor, J. Chem. Phys. 97, 6549 (1992).

${ }^{21}$ K. A. Peterson, J. Chem. Phys. 102, 262 (1995).

${ }^{22}$ R. C. Mawhinney, P. J. Bruna, and F. Grein, Chem. Phys. 199, 163 (1995).

${ }^{23}$ R. R. Reddy, Y. N. Ahammed, K. R. Gopal, P. A. Azeem, and S. Anjaneyulu, Astrophys. Space Sci. 262, 223 (1999).

${ }^{24}$ J. M. L. Martin, J. P. François, and R. Gijbels, J. Chem. Phys. 90, 6469 (1989).

${ }^{25}$ J. M. L. Martin, J. P. François, and R. Gijbels, Chem. Phys. Lett. 193, 243 (1992).

${ }^{26}$ Z. Slanina, J. M. L. Martin, J.-P. François, and R. Gijbels, Chem. Phys. Lett. 201, 54 (1993).

${ }^{27}$ J. M. L. Martin, P. R. Taylor, J. P. François, and R. Gijbels, Chem. Phys. Lett. 222, 517 (1994).

${ }^{28}$ A. Sutjianto, R. Pandey, and J. M. Recio, Int. J. Quantum Chem. 52, 199 (1994).

${ }^{29}$ J. M. L. Martin, J. El-Yazal, J.-P. François, and R. Gijbels, Mol. Phys. 85, 527 (1995).

${ }^{30}$ J. M. L. Martin, J. El-Yazal, and J.-P. François, Chem. Phys. Lett. 248, 95 (1996).

${ }^{31}$ M. S. Deleuze, M. G. Giuffreda, J.-P. François, and L. S. Cederbaum, J. Phys. Chem. A 104, 1588 (2000).

${ }^{32}$ M. Sai Baba, R. Viswanathan, and K. A. Gingerich, in Proceedings of the IX International Conference on High Temperature Materials Chemistry, edited by K. E. Spear (The Electrochemical Soc. Inc., Pennigton, N.J., 1997), Vol. 97-39, p. 689.

${ }^{33}$ R. Viswanathan, R. W. Schmude, Jr., and K. A. Gingerich, J. Chem. Thermodyn. 27, 1303 (1995).

${ }^{34}$ K. A. Gingerich, R. Viswanathan, and R. W. Schmude, Jr., J. Chem. Phys. 106, 6016 (1997).

${ }^{35}$ G. Meloni and K. A. Gingerich, J. Chem. Phys. 111, 969 (1999).

${ }^{36}$ G. Meloni, R. Viswanathan, and K. A. Gingerich, J. Chem. Phys. 111, 9325 (1999)

${ }^{37}$ G. Meloni and K. A. Gingerich, J. Chem. Phys. (to be published).

${ }^{38}$ Gaussian 98, Revision A.6, M. J. Frisch, G. W. Trucks, H. B. Schlegel et al. Gaussian, Inc., Pittsburgh, PA, 1998.

${ }^{39}$ F. R. Ornellas and S. Iwata, J. Phys. Chem. 100, 10919 (1996).

${ }^{40}$ D. J. Brugh and M. D. Morse, Chem. Phys. Lett. 267, 370 (1997).

${ }^{41}$ L. Andrews, M. Zhou, G. V. Chertihin, W. D. Bare, and Y. Hannachi, J. Phys. Chem. A 104, 1656 (2000).

${ }^{42}$ K. A. Gingerich, in Current Topics in Materials Science, edited by E. Kaldis (North-Holland, Amsterdam, 1980), Vol. 6, p. 345.

${ }^{43}$ R. C. Schoonmaker, A. Buhl, and J. Lemley, J. Phys. Chem. 69, 3455 (1965).

${ }^{44}$ D. L. Hildenbrand and W. F. Hall, J. Phys. Chem. 67, 888 (1963).

${ }^{45}$ C. E. Moore, NSRDS-NBS 35, Natl. Bur. Stand. US (1971).

${ }^{46}$ Thermodynamic Properties of Individual Substances, edited by L. V. Gurvich, I. V. Veyts, and C. B. Alcock (Begell House, New York, 1996), Vol. 3.

${ }^{47}$ D. K. Stull and H. Prophet, in Characterization of High Temperature Vapors, edited by J. L. Margrave (Wiley Interscience, New York, 1971), p. 359.

${ }^{48}$ R. W. Kiser, Introduction to Mass Spectrometry and Its Applications (Prentice-Hall, Englewood Cliffs, N.J., 1965). 
${ }^{49}$ J. B. Mann, Proceedings in Recent Developments in Mass Spectrometry, edited by K. Ogata and T. Hayakawa (University of Tokyo, Tokyo, 1970), p. 814.

${ }^{50}$ R. S. Freund, R. C. Wetzel, R. J. Shul, and T. R. Hayes, Phys. Rev. A 41, 3575 (1990).

${ }^{51}$ E. Brook, M. F. A. Harrison, and A. C. H. Smith, J. Phys. B 11, 3115 (1978).

${ }^{52}$ M. W. Chase, Jr., C. A. Davies, J. R. Downey, Jr., D. J. Frurip, R. A. McDonald, and A. N. Syverud, JANAF Thermochemical Tables, 3rd ed., edited by D. R. Lide, Jr. (American Institute of Physics, New York, 1986). ${ }^{53}$ R. W. Schmude, Jr., Q. Ran, and K. A. Gingerich, J. Chem. Phys. 99, 7998 (1993).

${ }^{54}$ L. V. Gurvich, G. V. Karachevstev, V. N. Kondrat'yev, Y. A. Lebedev, V. A. Mendredev, V. K. Potapov, and Y. S. Khodeev, Bond Energies, Ionization Potentials, and Electron Affinities (Nauka, Moscow, 1974), in Russian.

${ }^{55}$ W. A. Chupka, J. Berkowitz, C. F. Giese, and M. G. Inghram, J. Phys. Chem. 62, 611 (1958) 
Journal of Chemical Physics is copyrighted by AIP Publishing LLC (AIP). Reuse of AIP content is subject to the terms at: http://scitation.aip.org/termsconditions. For more information, see http://publishing.aip.org/authors/rights-and-permissions. 